\title{
Notes
}

\section{Telex v. IBM: Monopoly Pricing under Section 2 of the Sherman Act}

\author{
In Telex Corp. v. International Business Machines Corp. (IBM), 1
} the district court for the Northern District of Oklahoma held ${ }^{2}$ that IBM violated $\S 2$ of the Sherman Act. $^{3}$ In its decision, the court confronted the unresolved issue of what pricing actions a lawfully acquired monopoly ${ }^{4}$ may take under $\$ 2$. This Note analyzes the Telex contribution to the monopoly pricing issue. ${ }^{5}$

1. 367 F. Supp. 258 (N.D. Okla. 1973) (amended judgment and decree), appeal docketed, Nos. 73-1874 to $1878,1961,1962$, 10th Cir., Nov. 30, 1973.

IBM has remained the giant of the computer industry (defined as general purpose digital computers and peripheral equipment, see note 63 infra) throughout the industry's 20-year existence, despite competition from other manufacturers of computer systems (now seven in number), computer leasing companies, and peripherals manufacturers such as Telex. See generally G. Brock, The United States Computer Industry 1954-1973, May 1973, at 27-82 (unpublished Ph.D. dissertation, Harvard Univ.). The pattern of competition in the industry is entry by a new rival, pricing or product response by IBM, and antitrust litigation by the competitor. See id. at 185-284, 323-63. Telex is IBM's first defeat on the merits in the mass of antitrust litigation challenging its dominant position in the computer industry. Although Control Data Corporaton, a systems manufacturer, settled its suit out of court in 1973, IBM faces pending actions by leasing companies. Greyhound Computer Corp. is appealing to the Ninth Circuit a 1972 directed verdict for IBM, Greyhound Computer Corp. v. IBM Corp., 1972 Trade Cas. 92,953 (D. Ariz.). And peripherals manufacturers are suing IBM. Five companies have filed suits in the wake of the Telex decision, THINk, July-Aug. 1974, at 5 (editorial introduction). The Justice Department suit, filed in January, 1969, is set for trial early in 1975. Id.

2. $367 \mathrm{~F}$. Supp. at 341,345 . The court awarded Telex injunctive relief and treble damages of $\$ 260$ million. The court held for IBM on Telex's claims under $\$ 1$ of the Sherman Act and $\$ 3$ of the Clayton Act, id. at 346.47, and awarded IBM $\$ 22$ million on its counterclaim for theft of trade secrets and copyright infringement. Id. at 358,362 .

3. 15 U.S.C. $\$ 2(1970)$ provides:

Every person who shall monopolize, or attempt to monopolize, or combine or conspire with any other person or persons, to monopolize any part of the trade or commerce among the several States, or with foreign nations, shall be deemed guilty of a misdemeanor....

4. The legal and economic analysis of this Note applies not only to monopoly firms and to oligopoly firms acting as joint monopolists, see note 18 infra, but also to the broader class of dominant firms, defined as those that possess more than 50 percent of the market and face a competitive fringe of small firms. F. SCHERER, INDUSTRIAL MARKET Structure and Economic Performance 165 (1970) [hereinafter cited as Scherer]. Absent a conspiracy, a dominant firm that does not possess monopoly power can only be liable under $\$ 2$ for attempt to monopolize. Attempt requires specific intent to monopolize but monopolization does not. See notes 39,90 infra. If the pricing actions of a firm with monopoly power do not violate $\$ 2$, the same actions by a firm without monopoly power are not a violation. Therefore, the conclusions of this Note with respect to monopoly pricing apply a fortiori to the dominant firm case.

5. This Note does not consider price discrimination by a monopoly between different purchasers of commodities of like grade and quality. Such price discrimination may violate the Robinson-Patman Act if its effect "may be substantially to lessen competition," 15 U.S.C. $\$ 13$ (a) (1970). A monopoly which discriminates in price between pur- 
Part I provides the economic and legal framework for the analysis of monopoly pricing. Economic theory suggests three basic models of monopoly pricing behavior. However, the legality of the three types of monopoly pricing is unclear under existing case law. Part II applies this framework to Telex. Of the three economic models, limit pricing best describes IBM's behavior, and the decision must be read as a holding against limit pricing under $\$ 2$. Part III argues that the Telex rule against limit pricing is bad economics and bad law. To prohibit limit pricing by a monopoly impairs the efficient allocation of resources and, given the monopoly's advantages over competitors, deprives consumers of the lowest prices attainable in the market. Moreover, Telex is inconsistent with the Supreme Court's approval of limit pricing under $\$ 7$ of the Clayton Act. ${ }^{\circ}$ Accordingly, the Telex holding that IBM's pricing actions violated $\S 2$ of the Sherman Act should be reversed.

\section{Economic Models and Legal Standards for Monopoly Pricing}

In a purely competitive market composed of many small sellers, each individual firm takes the prevailing market price as a given which it cannot perceptibly influence. ${ }^{7}$ At the other extreme, a pure monopoly supplies 100 percent of the market and, by restricting its output, can control price in the short run without concern for competitors. ${ }^{8} \mathrm{Be}$ -

chasers may also violate $\$ 2$ of the Sherman Act whether or not a Robinson-Patman violation is established. United States v. Standard Oil (N.J.), 221 U.S. 1, 32, 43 (1911); United States v. New York Great Atl. \& Pac. Tea Co., 173 F.2d 79, 87-88 (7th Cir. 1949); Power Replacements v. Air Preheater Co., 356 F. Supp. 872, 886-90, 897 (E.D. Pa. 1973) (also a Robinson-Patman violation); United States v. Grinnell Corp., 236 F. Supp. 244, 256 (D.R.I. $196-4)$, aff'd, $38 \div$ U.S. 563 (1966).

The legal definition of price discrimination under the Robinson-Patman Act-charging different prices to different purchasers of the same commodity-is not the same as the cconomic definition-price differentials not directly related to costs of supply. ScHERER, supra note 4 , at 253-72, 495-505. Price discrimination in the economic but not legal sense would occur if multiproduct firms realize different price-cost margins on items due to differences in demand conditions. Id. at 257. This Note does discuss such differential price-cost margins. See pp. 563,569 infra.

6. Section 7 of the Clayton Act provides:

No corporation engaged in commerce shall acquire, directly or indirectly, the whole or any part of the stock or other share capital and no corporation subject to the jurisdiction of the Federal Trade Commission shall acquire the whole or any part of the assets of another corporation engaged also in commerce, in any line of commerce in any section of the country, where the effect of such acquisition may be substantially to lessen competition, or to tend to create a monopoly.

15 U.S.C. $\$ 18$ (1970), as amended by Act of Dec. 29, 1950, ch. 1184, 64 Stat. 1125.

Other commentators have called attention to the Supreme Court's use of limit pricing theory in its potential competition decisions under $\$ 7$. See note 107 infra. This Note attempts to show the usefulness of limit pricing theory under $\S 2$ of the Sherman Act.

7. SCHERER, supra note 4, at 9-10.

8. Id. at 13-14. The short run is defined as the length of time during which the firm's plant and equipment are fixed. E. MANSFIfld, Microeconomics 117 (1970). Thus entry of potential competitors or expansion of existing competitors cannot occur in the short run. 
tween these extremes lies a spectrum of market power exhibited by firms in real world markets. ${ }^{9}$ At some point toward the pure monopoly end of the spectrum, the market power of the firm reaches the level which the courts conclude is monopoly power. ${ }^{10}$ The legal concept of monopoly is thus not restricted to the pure case of a firm with 100 percent of the market, but may include a dominant firm facing a fringe of smaller competitors. ${ }^{11}$

The market power of the firm in the long run depends on the extent of the barriers to the entry or expansion of competitors. These barriers are the technological and institutional advantages of the established firm which enable it to raise its price persistently above its minimal average cost without attracting new entry or expansion. ${ }^{12}$ Examples of such barriers include superior production techniques, access to limited supplies of raw materials, or economies of scale. Significant barriers to entry are a necessary condition for the existence of monopoly power; ${ }^{13}$ without them, a firm cannot control prices in the long run no matter how great its current market share, because potential competitors will enter and bid down the price.

Economic theory provides three models of pricing strategy for the profit-maximizing ${ }^{14}$ monopoly firm: umbrella, limit and "credible threat" pricing.

9. Handler, Some Unresolved Issues of Antitrust, 62 CoLum. L. REV. 930, 932-33 (1962).

10. A firm has monopoly power in the relevant market if it has the power to control prices or exclude competition. United States v. E.I. duPont de Nemours \& Co., 351 U.S. 377, 391 (1956). Monopoly power will ordinarily be inferred from a predominant ( 80 percent) share of the market. United States v. Grinnell Corp., 384 U.S. 563, 571 (1966); American Tobacco Co. v. United States, 328 U.S. 781, 797 (1946).

11. See, e.g., United States v. Paramount Pictures, Inc., 334 U.S. 131 (1948) (five motion picture producers, treated as one firm because of conspiracy, with 70 percent share); Besser Mfg. Co. v. United States, 96 F. Supp. 304 (E.D. Mich. 1951), aff'd, 343 U.S. 444 (1952).

12. For the classic theoretical and empirical work on entry barriers, see J. BAIN, Barriers to New Comperition (1956). Bain classified barriers in three categories-cconomies of scale, absolute cost advantages, and product differentiation-and estimated their over-all height in twenty manufacturing industries. For a discussion of the use of barriers in antitrust law, see Disner, Barrier Analysis in Antitrust Law, 58 CORNELL L. REV. 862 (1972).

13. See Scherer, supra note 4, at 10; C. Kaysen \& D. Turner, Antitrust Policy 77, 101 (1959). Although the most important criterion in determining monopoly power is the defendant's market share, United States v. Grinnell Corp., 384 U.S. 563, 571 (1966), courts have implicitly recognized that long periods of dominant market share almost always reflect substantial entry barriers. See, e.g., American Tobacco Co. v. United States, 328 U.S. 781, 798 (1946) (advertising and capital requirements); United States v. Aluminum Co. of America, 148 F.2d 416, 426 (2d Cir. 1945) (tariff and transportation barriers to foreign producers); United States v. United Shoe Mach. Corp., 110 F. Supp. 295, 340.42 (D. Mass. 1953), aff'd per curiam, 347 U.S. 521 (1954); United States v. Pullman Co., 50 F. Supp. 123 (E.D. Pa. 1943), aff'd per curiam, 330 U.S. 806 (1947).

14. This Note does not consider the pricing implications of other assumptions about firm objectives-for example, that managers seek to maximize sales rather than profits. See generally ScHERER, supra note 4 , at 27-36, 234-36. 


\section{A. Three Economic Models of Monopoly Pricing}

I. Umbrella Pricing. The simplest view of monopoly pricing is that the firm maximizes profits in the short run, producing at an output which equates its marginal cost and marginal revenue. ${ }^{15} \mathrm{New}$ firms enter the market, or existing firms expand, under the "umbrella" of high prices. The monopoly firm then adjusts its price to maximize again its short-run profits, taking into account the quantity which existing competitors will supply at a given price but ignoring the possibility of additional entry or expansion. ${ }^{16}$ Entry and expansion

15. Id. at 13-14.

16.

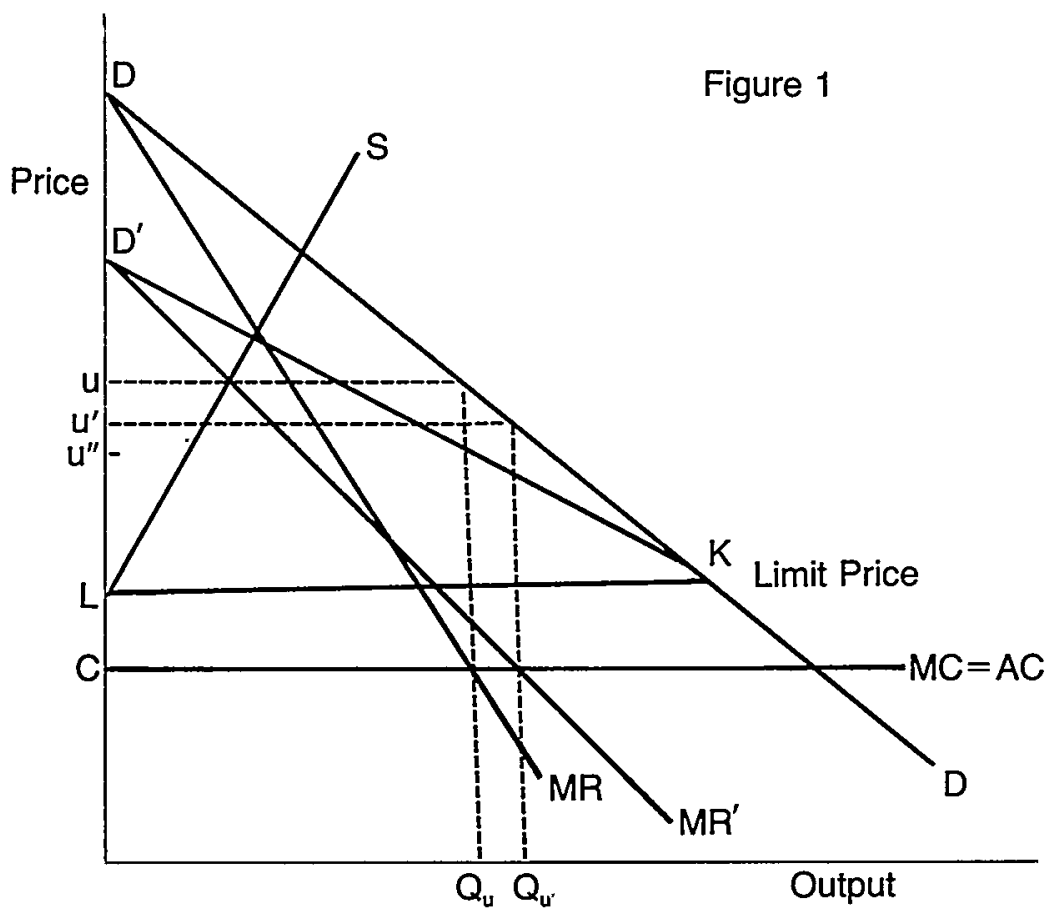

The umbrella pricing model is illustrated in Figure 1, a diagram adapted from $i d$. at 164-66. Assume (1) that the marginal cost $M C$ is constant, and hence equal to the average cost $A C$, and (2) that the monopoly initially has 100 percent of the market, and hence faces the industry demand curve $D K D$. It chooses an output $Q u$ which equates marginal revenue $M R$ with $M C$. The resulting umbrella price $U$ attracts a new entrant whose supply curve is $L S$. The monopoly now faces a more elastic demand curve $D^{\prime} K D$, obtained by subtracting the new entrant's supply curve from the industry demand curve; below $K$ the new entrant cannot produce and the monopoly faces the original industry demand curve. The monopoly now equates its new marginal revenue curve $M R^{\prime}$ with $M C$ and sets the price $U^{\prime}$, which is below $U$ but still far above its costs. The price $U^{\prime}$ induces further entry, generating a new supply curve and a still more elastic demand curve, which in turn results in a further drop in price to $U^{\prime \prime}$. 
will continue to erode the monopoly's market share and force it to reduce prices until no competitor can enter or expand at the prevailing market price.

2. Limit Pricing. Limit pricing models ${ }^{17}$ assume that the monopolist $^{18}$ recognizes in advance the threat posed by potential competitors. Instead of maximizing short-run profits, the firm sets its price just below the "limit price"-the price below which no potential competitor can enter the market and no existing competitor can expand. ${ }^{19}$ The limit pricing firm seeks to maximize profits in the long run by foregoing some short-run profits, deterring entry, and preserving market share.

Whether limit pricing does in fact maximize the monopoly firm's long-run profits depends on the level of the limit price relative to both the umbrella price and the firm's minimum average cost. If the limit price is calculated to be above the umbrella price, the firm can simply maximize short-run profits unconstrained by potential competitors. Where the limit price is below the umbrella price, the firm must compare the temporary profits it foregoes with the discounted value of long-run profits at the limit price. As the limit price approaches the firm's average cost, limit pricing becomes less profitable; at some point, it will not return sufficient long-run profits to outweigh the initially higher profits from short-run maximization. In this situation the firm will do better by umbrella pricing even though its market share is eroded by new entrants.

The level of the limit price is determined by the height of barriers to entry or expansion. If there are no barriers, the limit price will be equal to the minimum average cost of the firm in the market, which will attract new entrants whenever it seeks to raise prices above that minimum. But since barriers to entry are a necessary condition for the existence of monopoly power, ${ }^{20}$ a monopoly firm is likely to be protected by barriers sufficiently substantial to raise the limit price above

17. For the seminal work on limit pricing, see Bain, $A$ Note on Pricing in Monopoly and Oligopoly, 39 Am. Econ. Rev. 448 (1949). See SCHERER, supra note 4, at 219-36 \& n.28.

18. Limit pricing may also occur with oligopolists acting as joint monopolists. An oligopolistic market is one in which a few sellers have a large share of the market. See SCHERER, supra note 4, at 10 . The limit pricing hypothesis was originally offered to reconcile the theoretical proposition that oligopoly firms collude to maximize their joint profits, with empirical evidence demonstrating that prices in oligopolistic markets were persistently below short-run profit-maximizing levels. Bain, supra note 17, at $448-49$.

19. See Figure 1, supra note 16. The limit price was originally defined in the context of a collusive oligopoly seeking to deter the entry of new firms, Bain, supra note 17, at 454 , and then generalized in the single-firm monopoly case to include the possibility of expansion by a fringe of existing competitors. See note 24 infra. From the point of view of the monopoly firm whose market share is being reduced, the entry of new rivals and the expansion of existing rivals are analytically equivalent. See J. BAIN, supra note 12, at 5 .

20. See note 13 supra. 
the level at which the firm would prefer an umbrella to a limit pricing strategy. ${ }^{21}$ At the same time, empirical evidence indicates that barriers are almost never so high that the limit price would be above the umbrella price. ${ }^{22}$

Different markets will have entry barriers of different types and magnitudes, which result in different gaps between the limit price and minimum average cost. The limit pricing monopoly will therefore have different price-cost margins in each market; it may even engage in limit pricing in some and umbrella pricing in others. If entry conditions differ as to separate product lines within a single market, the firm's price-cost margins will reflect the different limit prices within the market.

Limit pricing theory has been refined since the early model which assumed that the firm had to choose between taking all its short-run profits or excluding all its potential competitors. Modern theory allows the monopoly firm to follow a flexible strategy, balancing its current profits against future market share. Under this dynamic model, the rate of entry depends on the size of the gap between the actual market price and the absolute limit price which deters all entry. ${ }^{23}$ The firm will gradually narrow the gap to retard the rate at which its market share is eroded until the entry and expansion of new competitors are absolutely forestalled at some equilibrium market share. ${ }^{24}$

21. The empirical evidence cited in note 30 infra indicates that firms with market power due to entry barriers often engage in limit pricing. Monopoly firms have the highest entry barriers and therefore are the most likely to engage in limit pricing.

22. Bain defines the case of limit price greater than umbrella price as "blockaded" entry, J. Bain, supra note 12, at 22. J.T. Wenders has shown that even in markets where Bain found "very high" barriers (limit price 10 percent above minimal average cost), a limit price above the short-run profit-maximizing price would be unrealistic. Given Bain's barrier estimates, the likelihood of blockaded entry is very slim. Wenders, Entry and Monopoly Pricing, $75 \mathrm{~J}$. POL. EcoN. 755 (1967). Government restrictions may, however, blockade entry, as in the case of state regulations which prohibit branch banking. United States v. Marine Bancorporation, Inc., 94 S. Ct. 2856, 2875-79 (1974).

23. Two factors support this hypothesis. (I) Some potential competitors can enter at lower prices than others, and hence their exclusion requires a correspondingly greater sacrifice of the monopoly's short-run profits. The monopoly is likely to allow the entry of these potential competitors who are very expensive to exclude. (2) Information is imperfect and forecasts uncertain about post-entry profits and prices. A small gap betwcen the market price and the absolute limit price will therefore attract only the Ieast riskaverse and most efficient potential competitors. SCHERER, supra note 4, at 224.

24. Gaskins used dynamic optimization techniques to formulate the model mathematically. Gaskins, Dynamic Limit Pricing: Optimal Pricing Under Threat of Entry, $3 \mathrm{~J}$. ECON. ThLORY 306 (1971). The monopoly firm is assumed to maximize the present value of profits over an infinite planning horizon, subject to the erosion of market share over time $(\mathrm{d} x / \mathrm{dt}$, where $\mathrm{x}(\mathrm{t})=$ level of rivals' shares). This crosion is given by a differential equation of the form

$$
\frac{\mathrm{dx}}{\mathrm{dt}}=\mathrm{k}(\mathrm{p}(\mathrm{t})-\overline{\mathrm{p}}) \text {, }
$$

where $\mathrm{k}$ is a coefficient measuring the speed of response by potential entrants and $\mathrm{p}$ is the limit price at which entry is absolutely forestalled. Gaskins showed that the market price $\mathrm{p}(\mathrm{t})$ will decline to the equilibrium value $\overline{\mathrm{p}}$ at which entry is precluded. Id. at 310 .

A similar mathematical specification was developed earlier by Pashigan, Limit Price 
3. Credible Threat Pricing. The third type of monopoly pricing behavior combines elements of the other two models to give the monopolist the best of both worlds. The established firm maximizes short-run profits but at the same time threatens to cut price below the limit price if entry occurs. Potential competitors are deterred by the realization that the price umbrella would be closed if they entered. In effect, the monopoly creates a psychological barrier to entry through threats of retaliatory price-cutting, which allows it to preserve its market share without sacrificing any profits.

The price-cutting threat must be credible to deter entry. ${ }^{25}$ The monopoly firm must maintain sufficient excess capacity to expand output suddenly and reduce price sharply if entry occurs. ${ }^{26}$ The firm must also develop a reputation for retaliating against new entrants. It may have to "teach a lesson" to the first new entrant in order to persuade others not to enter. ${ }^{27}$ Establishing a credible price-cutting

and the Market Share of the Leading Firm, 16 J. Indus. Econ. 165 (1968), to determine the point in time at which the firm switches abruptly from the short-run maximizing price to the absolute entry-deterring limit price. SCHERER, supra note 4 , at $224 \mathrm{n} .42$. This model generates results similar to Gaskins' more general formulation which allows for continuous adjustments in price.

25. Telser, Cutthroat Competition and the Long Purse, 9 J. LAw \& Econ. 259 (1960), was the first to present a formal analysis of predatory pricing as a credible threat directed at potential entrants. He argued that the credibility of the threat depended on the ability of the firm to sustain losses longer than its rivals and hence required a "long purse." Id. at 263-69.

26. For an explicit model based on the hypothesis that a monopoly or oligopoly will carry excess capacity to deter entry, see M. Spence, Entry, Capacity, Investment and Oligopolistic Pricing, Apr. 1974 (Tech. Rep. No. 131, Inst. for Math. Stud. in the Soc. Sci., Stanford Univ.).

27. Price-cutting by a monopoly below its own costs to drive out a rival is commonly termed "predatory pricing." Yamey, Predatory Price Cutting: Notes and Comments, $15 \mathrm{~J}$. LAw \& EcoN. 129 (1972). The credible threat model broadens the economic analysis of predatory pricing from the classic situation of pricing below the firm's own cost to include price-cutting below a competitor's costs. The two situations involve the same principle: The monopoly sacrifices profits temporarily to drive out a new rival and then restores the monopoly price. Yamey, supra, at 132-37. The difference between the two cases is that "below own cost" pricing is unambiguous evidence of predatory intent since the price cuts can only be temporary, while "below rival's cost" pricing may be a permanent reduction to a limit price. The judgment of whether price cuts are part of a predatory "credible threat" strategy or a limit pricing strategy depends on whether the cuts are interpreted as "permanent" or "temporary."

This Note uses the term "credible threat" rather than the traditional "predatory" label for two reasons. First, it avoids confusion with the use of the term "predatory" in the case law to mean evidence of a specific intent to monopolize, see note 59 infra. Second, it emphasizes the importance of the "lesson-teaching" element in temporary price-cutting. Recognition that the costs incurred in driving out one rival generate benefits in deterring others is one factor which has led to a questioning of the view once widely held by economists that predatory pricing is generally an unprofitable, and hence unlikely, strategy for a monopoly to follow. Compare Yamey, supra, at 130-31 and Posner, Exclusionary Practices and the Antitrust Laws, 41 U. CHr. L. Rev. 506, 516-17 (1974) with McGhee, Predatory Price Cutting: The Standard Oil (N.J.) Case, 1 J. LAw \& EcoN. 137, 143, 168 (1958). 
threat is difficult in markets where demand is growing ${ }^{28}$ or barriers to entry are low. ${ }^{29}$

The behavioral assumption of each model may be criticized on theoretical grounds. ${ }^{30}$ The umbrella pricing model seems unrealistic because it assumes that the monopoly firm ignores the threat of potential competitors even after their entry has eroded its market share; the firm continues its one-period maximization without learning from experience. The limit pricing model assumes that potential competitors view the existing market price as an accurate predictor of the post-entry price.$^{31}$ But potential entrants may ignore the market price in making the entry decision because they fear a post-entry price-cutting response by the monopoly firm, because they view the pre-entry price as a bluff, or because they place greater emphasis on other factors, such as the rate of growth of demand. ${ }^{32}$ If potential entrants do ignore the

28. The monopoly must correctly forecast a growing demand in order to maintain excess capacity; it faces a difficult choice between overinvesting in surplus facilities or risking a capacity constraint. See Scherer, supra note 4, at 229. A rapid growth of demand also increases the attractiveness of entry to potential competitors. See G. SrIGLER, THL Theory of Price 227, 344 (3d ed. 1966).

29. If entry is easy, potential competitors will be strongly tempted to enter, or reenter, whenever the monopoly reinstates its umbrella price. Predatory pricing will be unattractive to the monopolist unless entry barriers are substantial. ScHERER, supra note 4 , at 275-76. See Telser, supra note 25 . But see Yamey, supra note 27, at 142.

30. The ultimate test of any theory, however plausible, is whether it is substantiated by the empirical evidence. The limit pricing hypothesis is supported by statistical analyses of entry and price data and by industry case studics.

ScIIERER, supra note 4 , at 232 , cites the inclastic demand estimates found in concentrated industrics as evidence of limit pricing. If demand is inclastic, a price increase will result in a smaller percentage decrease in output, thus adding to total revenue. Therefore, monopoly firms maximizing short-run profits will raise price above the level where demand is inclastic. Further statistical support is provided by the most recent empirical study of markets experiencing entry, which concluded that dynamic limit pricing is a possible explanation of observed entry data. M. Harris, Entry, Barriers to Entry, and Limit Pricing, 1973 (unpublished Ph.D. disscrtation, Columbia Univ.).

Industry case studies have also produced evidence of limit pricing, notably by Xerox in the copying machinc market. SctIERER, supra note 4, at 225, 232-33. Schercr also points out that some entry in industries with high barriers, cited by critics as evidence that limit pricing is not a common strategy, is consistent with dynamic limit pricing theory. Id. at 224. Highly relevant to the market involved in this Note are the results obtained by $G$. Brock, supra note 1 , at $152-83$, who fitted a dynamic limit pricing model to the computer systems market and found that the model "quite accurately" represented IBM's pricing, profits and market shares from 1956 to 1972.

31. In the special case where the barrier to entry is economies of scale, the limit pricing model postulates that potential competitors assume the established firm will hold its output constant in the face of large scale entry and that the market price will fall because of the addition of new output to that of the established firm. This postulate of output maintenance has also been criticized as unrealistic. SCHERER, supra note 4, at 225-29.

32. Many of the objections to limit pricing theory are considered in recent works on more complex models which: e.g., relax the potential entrant's assumption that the current market price will be in effect after entry, Baron, Limit Pricing, Potential Entry, and Barriers to Entry, 63 AM. ECoN. REv. 666, 667 (1973); make entry a stochastic event whose probability depends on the market price-limit price gap, Kamien \& Schwartz, Limit Pricing and Uncerlain Entry, 39 EconomerRICA 441 (1971); and include other detcrminants of entry in addition to price, id. (rate of growth of demand). For one example of the advantage in using a probabilistic model, compare Goldberg \& Moirao, Limit Pricing and Potential Competition, 81 J. PoL. Econ. 1460 (1973), with Sherman \& Willett, Potential Entrants Discourage Entry, 75 J. PoL. Econ. 400 (1967). 
existing market price, there is no reason for the monopoly to engage in limit pricing. Finally, credible price-cutting threats require particular demand and entry conditions in the market which may not be fulfilled. The actual strategy followed by the monopoly will depend on the structural characteristics of the given market, and may combine elements of all three models. ${ }^{33}$

\section{B. Legal Standards for Monopoly Pricing}

A firm may lawfully acquire or maintain monopoly power under the Sherman Act through "a superior product, business acumen, or historic accident." 34 The innovator ${ }^{35}$ and the natural monopoly ${ }^{30}$ are both examples of legal monopolies. But the law puts limits on the conduct by which the monopoly firm seeks to maintain its lawfully acquired position; if it exceeds those limits, legal monopoly becomes illegal monopolization. ${ }^{37}$

33. E.g., Scherer, supra note 4, at 229, concludes that in the case of scale economy barriers the firm would most likely follow a two part strategy of limit pricing to deter small-scale entry and price-cutting threats to deter large-scale entry. See generally Spence, supra note 26, at 1, 25-26 (suggesting that in a homogeneous product market the firm will carry excess capacity, while in a nonhomogeneous market it will attempt to raise entry barriers by advertising or exclusive dealing contracts).

34. United States v. Grinnell Corp., 384 U.S. 563, 570-71 (1966). But see Williamson, Dominant Firms and the Monopoly Problem: Market Failure Considerations, 85 Harv. L. REV. 1512 (1972) (arguing that a general $\$ 2$ exemption is unwarranted for monopolies attributable to business acumen or historic accident).

The concept of lawful monopoly is well-established in antitrust law. See Standard Oil Co. (N.J.) v. United States, 221 U.S. 1, 62 (1911); United States v. Aluminum Co. of America, 148 F.2d 416, 429-30 (2d Cir. 1945) (monopoly "thrust upon" a firm not monopolization); Handler, supra note 9, at 933-34; Turner, The Definition of Agreement under the Sherman Act: Conscious Parallelism and Refusals to Deal, 75 HARv. L. Rev. 655, 667 (1962).

35. See, e.g., American Tobacco Co. v. United States, 328 U.S. 781, 786 (1946) (monopoly achieved by "a new discovery or an original entry into a new ficld" distinguished from illegal monopoly); United States v. Aluminum Co. of America, 148 F.2d 416, 430 (2d Cir. 1945) (monopoly achieved by "superior skill, foresight, and industry" permitted by Sher$\operatorname{man} A(t)$.

36. Courts have found natural monopolies in, e.g., Union Leader Corp. v. Newspapers of New England, Inc., 284 F.2d 582 (1st Cir. 1960), cert. denied, 365 U.S. 833 (1961); Ovitron Corp. v. General Motors Corp., 295 F. Supp. 373 (S.D.N.Y. 1969). For economic definitions of natural monopoly, see C. KAYSEN \& D. TURNER, supra note 13, at 191; Posner, Natural Monopoly and its Regulation, 21 STAN. L. REv. 548 (1969).

37. The distinction between monopoly and monopolization has been a longstanding issue in antitrust law. Early Supreme Court decisions implied that there was no monopolization unless the defendant had "abused" its monopoly power by resorting to predatory practices. United States v. United States Steel Corp., 251 U.S. 417 (1920); United States v. United Shoc Mach. Co., 247 U.S. 32 (1918). See United States v. United Shoe Mach. Corp., 110 F. Supp. 295, $314-25$ (D. Mass. 1953), aff'd per curiam, 347 U.S. 521 (1954); Levi, The Antitrust Laws and Monopoly, 14 U. CH. L. REv. 153, 157-60 (1947); Mason, Monopoly in Law and Economics, 47 YALE L.J. 34, 44 (1937). A landmark case, United States v. Aluminum Co. of America, 148 F.2d 416 (2d Cir. 1945), and its aftermath -American Tobacco Co. v. United States, 328 U.S. 781 (1946); United States v. Griffith, 334 U.S. 100 (1948)-gave rise to a "power" theory of monopolization which stated that mere possession of a monopoly, unless "thrust upon" the defendant, would suffice for monopolization. See United States v. United Shoe Mach. Corp., supra, at 341-42; Rostow, 
The limits imposed by the law are directed to both the intent of the monopoly firm and the effect of its activity. The law prohibits any conduct which evinces a specific intent to acquire or maintain monopoly power. ${ }^{38}$ But specific intent is not necessary for monopolization. ${ }^{30}$ A firm may be liable under $\S 2$ of the Sherman Act for normal business practices-such as expansion of capacity or long-term leaseswhich would have been legal if the firm had not already possessed monopoly power. ${ }^{40}$ Regardless of intent, a monopoly may not artificially impede the entry or growth of competitors. ${ }^{41}$

The case law does not make clear whether any of the three alternative pricing strategies suggested by economic theory would transform legal monopoly into illegal monopolization. The courts have not analyzed the facts before them in terms of these models, and it is difficult to determine which model, if any, fits the facts of a particular case. Nevertheless, it is possible to discern some guidelines for monopoly pricing from several leading monopolization cases.

1. Umbrella pricing. No case has held that a monopoly may not take maximum short-run profits, although it has been argued that an unreasonably high price may violate $\$ 2 .{ }^{42}$ The Supreme Court's landmark decision in United States $v$. United States Steel Corp..43 suggests

The New Sherman Act: A Positive Instrument of Progress, 14 U. ChI. L. Rev. 567, 575-86 (1947). Some commentators have tried to classify monopolization cases according to these two theories. See Note, Monopolization under Section 2 of the Sherman Act, 22 S.C.L. REv. 345 (1970); Note, Tclex v. IBM: Implications for the Businessman and the Computer Manufacturer, 60 VA. L. REv. 884, 896 (1974): "It is not clear which theory, the abuse theory or the Alcoa possession theory, was used to find monopoly power" possessed by IBM.

The better view is that monopolization requires more than power but less than abuse. See United States v. Grinncll Corp., 384 U.S. 563, 570.71 (1966) (separate conduct element, defined by "willful acquisition or maintenance" test, see p. 566 supra, distinguishes monopolization from monopoly); U.S. ATT'Y GEN.'s NA'T'L CoMM. TO STUDY THE ANTITRUST LAws, RePORT 55 (1955) (using the term "deliberateness" to describe the additional element required to turn monopoly into monopolization).

Commentators have recently suggested that a modified version of the "power" theory be used against firms which retain a monopoly position for a substantial period of time. Turner, The Scope of Antilrust and Other Economic Regulatory Policies, 82 HARv. L. REv. 1207, 1217-25 (1969); Williamson, supra note 34.

38. See, e.g., United States v. Grinnell Corp., 384 U.S. 563, 571, 576 (1966); Standard Oil Co. (N.J.) v. United States, 221 U.S. I, $75-76$ (1911).

39. United States v. Aluminum Co. of America, I48 F.2d 416, $431-32$ (2d Cir. 1945). Accord, United States v. Griffith, 334 U.S. 100 (1948).

40. United States v. Aluminum Co. of America, 148 F.2d 416, 431 (2d Cir. 1945); United States v. United Shoe Mach. Corp., 110 F. Stpp. 295, 344-45 (D. Mass. 1953), aff'd per curiam, 347 U.S. 521 (1954).

41. C. KAYSEN \& D. TURNER, supra note 13, at 21-22; Handler, supra note 9, at 934.

42. Handler, supra note 9, at 936, and Turner, supra note 36 , at 667 , argue that the courts have assumed an informal supervision over unregulated monopolies analogous to that of public utility commissions over monopolies regulated by statute. Handler further suggests that this supervision may extend to a prohibition against exploiting monopoly power by high prices. See United States v. Aluminum Co. of America, 148 F.2d 416, 426 (2d Cir. 1945).

43. 251 U.S. 417 (1920). 
that a monopoly may escape $\S 2$ condemnation by erecting a price umbrella which allows competitors to enter and grow. ${ }^{44}$

2. Limit pricing. Trwo leading monopolization cases, United States v. Aluminum Company of America, ${ }^{45}$ and United States v. United Shoe Machinery Corp. ${ }^{46}$ arguably imply that limit pricing by a monopoly constitutes illegal monopolization. In Alcoa, Judge Learned Hand held that while Alcoa had legitimately acquired its monopoly of virgin aluminum ingot by patents, ${ }^{47}$ it had illegally maintained that monopoly by expanding capacity to meet the eightfold growth of demand for aluminum. ${ }^{48}$ The most plausible interpretation of the court's findings on Alcoa's conduct is that Alcoa was limit pricing to preserve its 100 percent share of domestic ingot production. ${ }^{49}$ The decision may be read to hold that a firm illegally monopolizes if it lowers price and expands output in order to keep a predominant share of the market. ${ }^{50}$

44. Even though it was formed by a consolidation giving it 65 percent of the market, 223 F. 55, 65 (D.N.J. 1915), the U.S. Steel Corporation was held not to have monopolized the steel industry. In a celebrated dictum, the Supreme Court said that "the law does not make...the existence of unexerted power an offense." 251 U.S. at 451 . As evidence that U.S. Steel had not exerted whatever power it possessed, the Court cited the erosion of the company's market share in the 10 years after its formation, and the testimony of competitors that they were not in any way restrained by the company's prices. Id. at 446; see $223 \mathrm{~F}$. at $65,78,92,97$. The Court seemed to equate umbrella pricing with unexerted monopoly power and to imply that a monopoly could escape condemnation by keeping prices high enough to allow competitors to enter and grow. Accord, United States v. Int'] Harvester Co., 274 U.S. 693, $708-09$ (1927).

45. 148 F.2d 416 (2d Cir. 1945).

46. 110 F. Supp. 295 (D. Mass. 1953), aff'd per curiam, 347 U.S. 521 (1954).

47. 148 F.2d at $422-23$.

48. Judge Hand said that Alcoa effectively excluded competitors and forestalled entry by "doubling and redoubling its capacity before others entered the field." Id. at 431 .

49. Expansion of capacity is necessary for limit pricing in a growing market. Unless the firm maintains an efficient scale of production by staying on its long-run average cost curve, market price will rise above the limit price as demand outstrips existing capacity.

Alternative explanations of Alcoa's conduct are not plausible. Alcoa's expansion was incompatible with an umbrella pricing strategy. An umbrella pricing firm would let its capacity lag behind demand with the excess absorbed by new entrants. Moreover, there are two ways in which Alcoa's expansion might have deterred entry while maximizing short-run profits: depriving competitors of necessary raw materials to blockade entry (in effect, raising the limit price above the umbrella price, see pp. 562-63 supra) or maintaining excess capacity to make credible an implicit price-cutting threat, see p. 564 supra. Both the barrier-raising and credible threat explanations are inconsistent with the court's finding that Alcoa made only "fair" profits of approximately 10 percent on its investment, $148 \mathrm{~F} .2 \mathrm{~d}$ at 426 , and thus was not taking maximum short-run profits. In addition, Judge Learned Hand accepted the trial court's finding that in acquiring ore deposits and water power sources which it did not fully use, Alcoa intended to provide for its future supply and not to blockade entry by competitors. Id. at 432-34. But see C. KAYSEN \& D. TURNER, supra note 13 , at 107.

50. "Alcoa meant to keep, and did keep, that complete and exclusive hold upon the ingot market with which it started. That was to monopolize that market, however innocently it otherwise proceeded." 148 F.2d at 432. See SCHERER, supra note 4, at 460 (decision may be read to condemn "dominant market positions maintained merely through limit pricing"). But see Bailey's Bakery, Ltd. v. Continental Baking Co., 235 F. Supp. 705, 719 (D. Hawaii 1964), aff'd per curiam, 401 F.2d 182 (9th Cir. 1968), cert. denied, 393 U.S. 1089 (1969) (holding insufficient in law the plaintiff's allegation that the defendant baking company, which had 80 percent of the Hawaiian bread products 
United Shoe may be read as a restriction on limit pricing by a multiproduct firm. The United Shoe Machinery Corp. had approximately 85 percent of the broadly defined shoe machinery market, ${ }^{51}$ and followed a general policy of preserving its market share by accepting lower profit margins where it faced competition. ${ }^{52}$ Although Judge Wyzanski did not rely on its differential profit margins for his holding that United monopolized the shoe machinery market, ${ }^{53}$ he did condemn them as a "buttress" to United's monopoly power. ${ }^{54}$ He refused to enjoin the practice in his decree, because the probibition would be impossible for a court to enforce. ${ }^{55}$ But under his reasoning a monopoly firm might still be liable for treble damages if it reduces prices selectively on individual products ${ }^{56}$ within a broad market in order to prevent competitors from taking a larger share. ${ }^{57}$

3. Credible threat pricing. American Tobacco Co. v. United States ${ }^{58}$ involved a clear example of credible threat pricing. The Big Three cigarette producers cut prices to combat the rapid growth of the cheaper "ten cent" brands during the Depression. Two of the Big Three sold at a loss. A year later, after sales of ten cent brands had fallen from 23 percent to 6 percent of the national cigarette market, the Big Three raised prices nearly to previous levels. The Supreme Court held this activity to be circumstantial evidence of a specific intent to monopolize.50

market, kept its prices three cents below West Coast levels "to keep out mainland competition, to forestall supermarkets from having their own bakeries, and to maintain [defendants'] own position in the market").

51. $110 \mathrm{~F}$. Supp. at $302-07$.

52. Id. at 325-29; C. Kaysen, United States v. United Shoe Machinery Corporation 125-34 (1956) (memorandum to court by economist serving as law clerk to Judge Wyzanski). Note that both Kaysen and the court apply the term "discrimination" in its economic, not legal, sense to mean differential profit margins on separate products.

Posner, supra note 27, at 531, interprets the United Shoe price reductions as umbrella pricing responses to a more elastic demand. But United Shoe cut prices to preserve a predominant market share, not to maximize short-term profits while allowing that share to erode, and its strategy is therefore properly viewed as limit pricing. See generally Disner, supra note 12, at 894.

53. United's leasing system was the crucial element in the illegal maintenance of its monopoly power. $110 \mathrm{~F}$. Supp. at $343-45$.

54. Id. at 349. See id. at $340-41,343$.

55. Id. at 349 .

56. Selective limit pricing may occur in different locations within a geographical market as well as in different product lines with a single product market. In the former case, it overlaps with the Robinson-Patman Act provision against area price discrimination, see note 5 supra, and is therefore outside the scope of this Note.

57. Judge Wyzanski's dictum that the monopoly might escape liability by "low profits maintained permanently without discrimination," 110 F. Supp. at 342, does not necessarily exempt even nonselective limit pricing, because limit pricing yields the maximum profits for the firm over the long run.

58. 329 U.S. 781, 805-07 (1946). See United States v. Corn Products Refining Co., 234 F. 964 (S.D.N.Y. 1916) (L. Hand, J.), appeal dismissed, 249 U.S. 621 (1919).

59. A long line of "predatory pricing" cases has held price-cutting by a monopoly below its own costs to drive out competitors to be evidence of specific intent. E.g., United States v. American Tobacco Co., 221 U.S. 106, 160, 181-82 (1911); Credit Bureau Reports, 
The legal standards applicable to each of the three types of pricing behavior are not clearly defined by the case law. Taken together, $U . S$. Steel, Alcoa, and United Shoe prefer umbrella pricing to limit pricing: ${ }^{60} \mathrm{But}$, unlike pricing below one's own cost, limit pricing has not been held to be evidence of a specific intent to monopolize. ${ }^{61}$ Finally, the monopoly might even be able to engage in credible threat pricing by reducing its prices below a competitor's costs, provided that it does not cut its prices below its own costs. ${ }^{62}$

\section{Telex and Limit Pricing}

Telex $v . I B M$ squarely presents the monopoly pricing issue. The district court defined the relevant market as peripheral equipment that is plug-compatible with IBM computers ${ }^{63}$ and held that IBM possessed monopoly power in that market. ${ }^{64}$ When IBM introduced its System

Inc. v. Retail Credit Co., 358 F. Supp. 780, 791-93 (S.D. Tex. 1971), aff'd on other grounds, 476 F.2d 989 (5th Cir. 1973); Ovitron Corp. v. General Motors Corp., 295 F. Supp. 373, 378 (S.D.N.Y. 1969); Bergjans Farm Dairy Co. v. Sanitary Milk Producers, 24I F. Supp. 476, 483-86 (E.D. Mo. 1965), aff'd, 368 F.2d 679 (8th Cir. 1966). See Note, Sales Below Cost Prohibitions: Private Price Fixing under State Law, 57 YALE L.J. 391, 399 n.27 (1949).

60. Posner, supra note 27, at $\mathbf{5 3 2 .}$

61. United States v. Aluminum Co. of America, 148 F.2d 416, $431-32$ (2d Cir. 1945); United States v. United Shoe Mach. Corp., 110 F. Supp. 295, 346 (D. Mass. 1953), aff'd per curiam, 347 U.S. 521 (1954).

62. The predatory pricing cases have not condemned price cuts that were below a competitor's costs but above the monopoly's costs. Courts have approved price cuts below a competitor's costs by a firm fighting for survival in a natural monopoly market. See Union Leader Corp. v. Newspapers of New England, Inc., $180 \mathrm{~F}$. Supp. 125, 143 (D. Mass. 1959), modified, 284 F.2d 582 (1st Cir. 1960), cert. denied, 365 U.S. 833 (1961); Lamb Enterprises, Inc. v. Toledo Blade Co., 461 F.2d 506, 515 (6th Cir.), cert. denied, 409 U.S. 1001 (1972); American Football League v. National Football League, 323 F.2d 124, 131 (4th Cir. 1963); Parmelee Transp. Co. v. Keeshin, 292 F.2d 794, 803-04 (7th Cir.), cert. denied, 368 U.S. 944 (1961).

63. The court also defined submarkets in five classes of peripheral devices: tape drives, disk drives, memories, printers, and communications controllers. $367 \mathrm{~F}$. Supp. at 282. The peripheral equipment of a computer system consists of the auxiliary devices which perform input, output, and storage functions. Peripherals attach to the central processing unit (CPU), which performs computations and logical operations. A peripheral device is "plug-compatible" with a given CPU if it fits the electronic specifications of the CPU and thus can be used with that CPU. 367 F. Stpp. at 274-75; Note, supra note 37 , at 885 . The term "peripherals" may be somewhat misleading, because peripheral products account for 50 to 75 percent of the price of a computer system. $367 \mathrm{~F}$. Supp. at 277.

64. 367 F. Supp. at 291,340 . This Note assumes that the Telex court was correct both in defining the market to be peripheral equipment that is plug-compatible with IBM computers and in holding that IBM possessed monopoly power in that market. Both issues raise difficult questions. The Telex market definition has been criticized in the literature. See Posner, supra note 27, at 521 (market "incorrectly defined" in Telex case); Rostow, The Origins and Intent of Antitrust Law, THink, July-Aug. 1974, at 63-64. The court's determination of monopoly power is also open to challenge. Its findings that entry was "initially easy for plug-compatible manufacturers" and that their entry "substantially eroded" IBM's market share, 367 F. Supp. at 286-87, suggest that IBMf may not have possessed the requisite "power to control prices or exclude competition." Id. at 335. See N.W. Controls, Inc. v. Outboard Marine Corp., 333 F. Supp. 493, 515-17 (D. Del. 
360 computers in 1964 , it had a legitimate 100 percent share of the market for its own peripherals. ${ }^{65}$ However, new entrants, including plaintiff Telex, rapidly eroded IBM's share. In 1970, IBM responded by cutting prices and offering one- and two-year leases at substantial discounts under its Fixed Term Plan (FTP). ${ }^{66}$ The court held that by its pricing and leasing practices, ${ }^{67}$ IBM monopolized and attempted to monopolize in violation of $\$ 2$ of the Sherman Act.

Of the three economic models presented in Part $\mathrm{I}$, limit pricing best describes IBM's price reductions. ${ }^{68}$ The court's holding that these price reductions violated $\S 2$ is a clear prohibition against limit pricing by a monopoly firm.

\section{A. The Economic Model in Telex}

Both umbrella pricing and credible threat pricing have been urged as interpretations of IBM's pricing behavior. Professor Posner has suggested that IBM was following an umbrella strategy ${ }^{69}$ He explains the

1971); United States v. American Can Co., 230 F. 859, 879-80, 892, 900 (D. Mfd. 1915). The Telex court reasoned that this entry had occurred before IBMf exercised its market power against PCM's, and therefore did not negate the existence of monopoly power. $367 \mathrm{~F}$. Supp. at 287.

65. 367 F. Supp. at $287,306$.

66. By 1970, IBM's share of disk and tape drives installed on its computers had dropped to 94 percent and 80 percent respectively, with forecasts of further losses in those markets and in printers and memory products. Id. at 287, 297-99, 304. In response to increasing plug-compatible competition, IBM made four substantial price reductions: the first two by repackaging its standard disk drive (2314) in a lower priced model $(2319 . A$ and $B$ ), the third by reducing prices between 20 and 35 percent on one- and twoyear leases of a variety of disk, tape, and printer devices under its Fixed Term Plan (FTP), and the fourth by introducing new low priced memory technology. Id. at 293, 295, 299,304 . This Note treats the FTP and the 2319 only as price cuts.

67. This Note does not discuss IBM's leases, apart from the price reductions which accompanied them. However, the holding that the leases violated the Sherman Act raises substantial problems. Compare IBM's optional one- and two-year leases, 367 F. Supp. at 299. 346, with those held to monopolize in United States v. United Shoe Mach. Corp., 110 F. Supp. 295, 314-25 (D. Mass. 1953), aff'd per curiam, 347 U.S. 521 (1954).

68. IBM's position at trial and on appeal fits none of the models. IBM argued that it was in a competitive market which forced it to cut price to meet the price set by competitors. IBM Proposed Findings of Fact, at 113-25, and Conclusions of Law, at 30-32. See Brief for Defendant-Appellant at 78, 87-88, 92, IBM Corp. v. Telex Corp. (10th Cir., filed Feb. 7, 1974) [hereinafter cited as IBM APPEAL BRIEF]. Even if IBM did not have monopoly power, its dominant market share, 10 percent cost advantage and ability to com. mand a premium for its products, $367 \mathrm{~F}$. Supp. at $287-90,294,345$, would give it enough power over price to make the economic models of Part I relevant to an analysis of its pricing behavior. IBM predicted that its competitors' shares would increase only to between 20 and 50 percent of the peripherals market by 1976 even if it did not reduce price at all, id. at 299.300 , indicating that IBM's demand curve was far from horizontal.

69. Posner, supra note 27, at 521:

As a result [of Telex's entry] the demand curve facing IBM became more elastic, the profit-maximizing monopoly price fell, and IBM lowered its price.

Sec note 16 supra. Posner's view of IBM's price reductions leads him to interpret the decision as requiring the monopoly to hold price above the short-run profit-maximizing level once entry occurs-in effect, as freezing the price at the pre-entry umbrella level. losner, supra note 27 , at 527 . This "curious" and "inadvertent" result, id, at 530 , may be avoided by using either of the other two monopoly pricing models to analyze the case. 
reductions as the result of short-run profit maximization taking into account the quantity supplied by the new entrants at a given price. In this view, IBM simply repeated its pre-entry price calculation subject to a new constraint which made its demand curve more elastic.

This view overlooks what the court saw as crucially important: IBM intended its price cuts to impede the growth of existing competitors and forestall entry into other plug-compatible peripheral markets. ${ }^{70}$ After initial disk drive price reductions failed to stop the erosion of its market share, IBM made further price cuts of between 20 and 35 percent. ${ }^{71}$ It also took action to forestall potential entry in the printer and memory submarkets where it did not yet face any actual plugcompatible competition. Top management assigned task forces to determine the price at which plug-compatible competitors could enter the memory market, ${ }^{2}$ and extended FTP discounts to printers as well as disk and tape drives. ${ }^{73}$ This focus on competitors' potential entry and future growth is inconsistent with an umbrella strategy and suggests a limit pricing strategy of sacrificing current profits to stop a projected loss of market share.

Telex's theory of the case was that IBM's price reductions were part of a credible threat strategy. Telex emphasized that IBM cut prices selectively on peripheral products facing plug-compatible competition, ${ }^{74}$ and argued that the lower prices would only last until plugcompatible competitors were driven out of the market. ${ }^{75}$ The mere fact of selective price reductions does not establish that IBM was following a credible threat strategy, since different profit margins by a multiproduct monopoly such as IBM are consistent with dynamic limit pricing behavior. ${ }^{78}$ The crucial question is whether the reductions

70. 367 F. Supp. at $293,297,345$.

71. Id. at 299.

72. Id. at 304 .

73. Id. at 298 .

74. Telex's Proposed Findings of Fact and Conclusions of Law Relating to Telex's Antitrust Claims at 60, 80-81, 90-91, Telex Corp. v. IBM Corp., 367 F. Supp. 258 (N.D. Okla. 1973) [hereinafter cited as TELEX Proposed Findings]; Brief for Plaintiff-Appellee at 75-76, IBM Corp. v. Telex Corp., No. 73-1874-1878, 1961-62 (10th Cir., filed Mar. 9, 1974), at 49-50, 57-58, 70-72 [hereinafter cited as TELEX APPEAL BRIEF]. The court found that the reduced price $2319 \mathrm{~A}$ disk drive could be used only with one model of IBM's System 370 computers, 367 F. Supp. at 293; that IBM omitted some categories of peripherals (e.g., card readers) from its FTP discounts and included only some of its disk and tape drive and printer models, id. at 298-99; and that IBM simultaneously maintained or raised its prices for CPU's, id. at 300,304 .

75. Record at 4512-4529 (Telex cross-examination of IBM economic expert), 6646-49, 6831-35 (oral argument). The Telex theory is clearly stated on appeal in TeLEx AppeaL BRIEF, supra note 74, at 75-77 (arguing that IBM had maintained a price umbrella before Telex entered and that IBM intended to do so again after it eliminated its plugcompatible competitors).

76. See p. 563 supra. 
were a temporary lesson-teaching tactic intended to enable IBM to raise a price umbrella without attracting new entrants. ${ }^{\mathbf{7 7}}$

The court's findings provide no convincing evidence that IBM followed a credible threat strategy. IBM did not reduce its price below its own costs or even its competitors' prices. ${ }^{78}$ It did not drive its plug-compatible competitors out of the market; at worst, it contained them by preventing further growth. ${ }^{79}$ Even assuming that IBM intended to drive them out, the court did not find that IBM intended to raise its prices afterward.80

The economic structure of the peripherals market would make it difficult to establish credible price-cutting threats, and it is unlikely that IBM would pursue such a strategy. Demand was growing rapidly, ${ }^{81}$ hampering any attempt at output restriction and making entry attractive to new competitors. Suppliers of peripherals for non-IBM computers could enter the market easily whenever IBM reinstated a price umbrella. ${ }^{82}$ Economists who have carefully analyzed other cases involv-

77. See note 27 supra.

78. In its amended findings filed one month after the initial decision, the court stated that IBM's reduced prices were intended to return a 20 percent profit, $i d$. at 306 , and were above the prices of its plug-compatible competitors except in four isolated instances, id. at 299. However, the court did not change its original finding, inconsistent with the amendments, that IBM tape drive prices were below, and were planned to be below, those of plug-compatible competitors. Id. at $\mathbf{3 4 5}$.

The relationship between the prices of IBM and those of its competitors is difficult to determine because of the premium commanded by IBM's substantially equivalent products. Id. Depending on the magnitude of this premium, IBM's reduction could be viewed as effectively below, even though nominally above, Telex's price. See Power Replacements Corp. v. Air Preheater Co., 356 F. Supp. 872, 890, 898 (E.D. Pa. 1973). Although an upper bound can be calculated, the size of the premium cannot be estimated exactly from the 20 to 50 percent price differentials existing before IBM's reduction, since IBM's market share was then rapidly declining. See G. Brock, supra note 1, at 128-29.

79 . 367 F. Supp. at 302 . The court relied on statistics which showed a leveling of the market shares of IBM's competitors after the IBM price cuts. Id. at 288. The market share charts included in the court's amended findings, however, show that this leveling was due to adding together the statistics for third and fourth generation peripherals. Competitors' shares for third generation equipment doubled after the IBM price cuts, but were balanced in the aggregate by IBM's new leases of fourth generation equipment which rapidly replaced the third generation and for which plug-compatible competitors did not yet have a copy. Id. at 288-90. Thus the leveling of plug-compatible shares, on which the court based its finding of "containing" competition, may be attributable to IBMI product innovation rather than price cuts.

80. Given IBM's past and pending antitrust problems from 1969 to 1972 , e.g., United States v. IBM Corp., 1956 Trade Cas. 71117 (S.D.N.Y.) (consent decree); United States v. IBMI Corp., [1961-70 Transfer Binder] Trade Reg. REP. I 45,069, at 52,707 (S.D.N.Y. 1969) (complaint filed), a blatantly predatory act such as restoring former price levels after eliminating Telex seems highly unlikely; cf. M. Adelman, A\&P: A STUdy IN PrIce-Cosr Behavior AND PUBLIC POLICY 407-10 (1959).

81. 367 F. Supp. at 285.

82. Entry in the plug-compatible market was "initially casy," and in six years the number of firms in the market grew from two or three to 100 . Id. at 286-87. Suppliers of peripherals compatible with non-IBM systems could develop, at a modest cost, an interface which would enable them to shift to the production of IBM-compatible equipment. Id. at 278. The court's suggestion that predatory pricing could make easy entry difficult, id., puts the cart before the horse: Easy entry makes predatory pricing difficult. See note 29 supra. 
ing allegedly predatory price-cutting in markets with low entry barriers have concluded that relatively easy entry made predatory pricing unattractive and that the price-cutter was actually following an umbrella or limit pricing strategy. .3

On the facts found by the court, the dynamic limit pricing model is the best description of IBM's price behavior. ${ }^{84}$ IBM sought to preserve its market share by trading short-run gains for maximum long-run profits. It sought to limit the share of existing and potential competitors by permanent reduction to a limit price, not by a temporary reduction to a lesson-teaching price.

\section{B. The Telex Rule Against Limit Pricing}

The Telex holding is a prohibition against limit pricing far stronger and more explicit than any implied by prior cases. The court first held that IBM's price cuts illegally maintained its monopoly under the Grinnell "willful acquisition or maintenance" test, which does not require specific intent to monopolize. ${ }^{85}$ Even without predatory intent, IBM was found to have monopolized by (1) lowering prices only on those types of peripherals facing the most threatening plug-compatible challenge, and (2) offsetting price cuts on peripherals by raising or maintaining prices on central processing units (CPU's). ${ }^{86}$ As to the first rationale, the court could have adopted the suggestion in United Shoe that a firm monopolizes if it selectively reduces prices on products

83. Three cases in which economists have found no predatory pricing are: (1) Standard Oil Co. (N.J.) v. United States, 221 U.S. I (1911) (see MicGhee, supra note 27, at 142, 168 (umbrella pricing); Scherer, supra note 4, at 275-76 (selective limit pricing)). (2) United States v. E.I. duPont de Nemours \& Co., 188 F. 127 (C.C.D. Del. 1911) (see Elzinga, Predatory Pricing: The Case of the Gunpowder Trust, 13 J. LAw \& Econ, 223, 236-37 (1970) (umbrella or limit pricing)). (3) United States v. New York Great Atl. \& Pac. Tea Co., 173 F.2d 79 (7th Cir. 1949) (see M. ADELMAN, supra note 80, at 14, 372-79, 407-10).

84. It is possible that IBM did erect a price umbrella from 1966 to 1969 before it recognized the threat posed by plug-compatible competitors. If so, its behavior would fit the special case of dynamic limit pricing modelled by Pashigan, supra note 24, in which the firm switches from short-run profit-maximizing to limit pricing at some point in the erosion of its share. The important point is that for the years relevant to Telex-1969 to 1972 , see $367 \mathrm{~F}$. Supp. at 306-IBM was clearly limit pricing.

This "switch-over" model seems to fit one discussion of IBM's pricing behavior, see Note, supra note 37, at 897-99, although the economic analysis in that discussion is somcwhat unclear: IBM maintained a price umbrella before 1970 because it sought "unusually high" profits in peripherals to recover its research and development costs, id. at 899; it then eliminated plug-compatible competitors by meeting their prices in an "ordinary competitive manner." $1 d$. at 898 . However, the umbrella price is determined by the interaction of marginal revenue and marginal costs, not by the recovery of sunk costs. Sec note 16 supra. In addition, "meeting competitors' prices" was effectively cutting to or below the limit price, because of the premium commanded by IBM's reputation for reliability and maintenance. See note 78 supra.

85. See pp. 566-67 supra.

86. 367 F. Supp at 341 . 
within a given market in which it has monopoly power. ${ }^{87}$ The court's offset theory, however, appears to have no legal or economic basis. ${ }^{8 s}$ The court put IBM in the unlikely posture of subsidizing reductions in the peripherals market, where the court found that IBM had monopoly power, with increases in the CPU market, where the court did not find monopoly power. ${ }^{89}$

The court went further: It held that IBM's price cuts were predatory acts manifesting a specific intent to monopolize. ${ }^{90}$ The court relied on IBM's intent to contain existing competitors and preserve its market share in the disk and tape submarkets. ${ }^{91}$ The court also cited IBM's attempt to prevent entry into the memory submarket by limit pricing; even though unsuccessful in deterring entry, IBM intended to monopolize because, in the court's view, IBM attempted "to fix a price for... memory that would influence potential plug-compatible competitors to stay out of the market." 92

87. See p. 569 supra. The United Shoe authority on selective price reductions was not argued to or cited by the court.

However, there is a substantial difficulty in applying this United Shoe principle in Telex. The "selectiveness" of multiproduct limit pricing may be due simply to overly broad market definition. There should be substantial cross-elasticity of demand or interchangeability of use among all products included in the same market. United States $\mathbf{v}$. E.I. duPont de Nemours \& Co., 351 U.S. 377, 394, 410 (1956). If the price of one product is decreased, consumers will substitute that product for others in the market. putting downward pressure on the prices of those other products. Selective price reductions will therefore tend to spread throughout the market, unless it includes products among which there is little cross-elasticity of demand. This argument raises the question of whether peripheral products on which IBM did not cut prices, e.g., card readers, 367 F. Supp. at 298, should have been included in the relevant market.

88. There seems to be no Sherman Act case which held differential price-cost margins in separate and distinct product markets to be illegal. Although the court did not cite authority for its offset theory, it might have reasoned from an analogy to RobinsonPatman cases involving price discrimination between purchasers in different geographical markets. See, e.g., Utah Pie Co. v. Continental Baking Co., 386 U.S. 685 (1967).

89. $367 \mathrm{~F}$. Supp. at 285-86. Even assuming that IBM had a monopoly in the CPU market but not in the peripherals market, a more fundamental problem with the offset theory is that if the firm is already exploiting monopoly power in the subsidizing (CPU) market, raising price will lower its profits. An offset or cross-subsidization strategy makes economic sense only for a firm operating in both regulated and competitive markets: By charging lower prices in the competitive market, it may be able to expand the rate base and increase its overall profit. See Noll \& Rivlin, Regulating Prices in Competitive Markets, 82 YALE L.J. 1426, 1427-28 (1973).

90. 367 F. Supp. at 345 . Because it found specific intent, the court also held that IBM violated $\S 2$ by an attempt to monopolize. Attempt to monopolize requires a specific intent to acquire monopoly power and a "dangerous probability" of doing so. See, e.g., Lorain Journal Co. v. United States, 342 U.S. 143 (1951); Cooper, Attempts and Monopolization: A Mildly Expansionary Answer to the Prophylactic Riddle of Section Two, 72 Mich. L. REv. 376, 378-408 (1974).

91. 367 F. Supp. at 345 . To describe IBM's intent the court used the words "contain," "retard growth," "suppress," and "eliminate" almost interchangeably, suggesting that it saw little legal significance in the differences among them. See, e.g., id. at 295, 306, 345 .

92. Id. at 304. On appeal, IBM argued that the court had confused two entirely distinct memory products-the old core type announced in 1970 with the first two models of System 370, and the new FET type announced in 1972. According to IBM, its task force estimated in 1970 that competitors would not be viable if they produced the first type at less than $\$ 6,000$ per month, but IBM's price on the old product was set at $\$ 12,000$ per 
Telex makes new law. There was no classic predatory behavior in the case. IBM did not cut prices below its own costs or discriminate in price between purchasers. ${ }^{93}$ The decision goes beyond the suggestions of earlier case law and holds that limit pricing is predatory. It prohibits the monopoly from setting a price low enough to prevent entry. When entry occurs, the monopoly is not allowed to reduce its price to stop the growth of new entrants. Under the Telex rule, the firm has no choice but to take short-run profits and face the steady erosion of its market share.

\section{The Arguments for Limit Pricing}

\section{A. The Economic Rationale for Limit Pricing: The Lowest Attain- able Market Price}

The economic goals of antitrust policy are efficiency in the allocation of resources and maximization of consumer welfare. ${ }^{94}$ These goals are fulfilled in a purely competitive market, where the long-run equilibrium price in the market is equal to the marginal cost and the minimum average cost of the representative firm in the market. ${ }^{95}$ The monopoly's long- and short-run market power enables it to maintain a price above the optimal level which would prevail in a purely competitive market. The closer the monopoly price to the competitive result the better the outcome in the market from an economic standpoint.

The umbrella price is above the marginal cost, because the monopoly's control over the market enables it to raise the price to a profitmaximizing level without losing all its business to existing competitors. As entry occurs, the umbrella price falls, but remains above the optimum as long as the firm's share remains large enough to give it

month; two years later IBM announced its new memory at $\$ 5,200-$ below the $\$ 6,000$ limit price for old memory but above the $\$ 2,700$ price at which IBM believed Telex could produce new memory. Brief for Defendant-Appellant at 91-94, IBM Corp. v. Telex Corp., appeal docketed, Nos. 73-1874 to 1878,1961 , 1962, 10th Cir., Nov. 30, 1973 (filed Feb. 7, 1974). The court's finding that competitors have announced new memory at "prices substantially below" IBM's, see 367 F. Supp. at 304, supports IBM's view of the facts. On these facts, IBM tried to retard entry in the memory submarket rather than prevent it altogether.

93. See notes 5,59 supra.

94. C. KAYSEN \& $\mathrm{D}$. TURNER, supra note 13, at 12; Bork, The Goals of Antitrust, 57 AM. EcoN. REv. 242 (Supp. May 1967) (goal of antitrust is "consumer welfare, defined as minimizing restrictions of output and permitting efficiency, however gained, to have its way"); Bork \& Bowman, The Crisis in Antitrust, 65 Colum. L. Rev. 363, 365 (1965).

95. SCHERER, supra note 4, at 12-13. This is the reason economists refer to the socially optimal price and output in a market as the "competitive result," and the reason they prefer competition to monopoly as a form of market organization. See id. at 18-19. 
some power over price. The gap between the umbrella price and marginal cost produces excess profits and misallocation of resources. ${ }^{96}$ In addition, the umbrella pricing monopoly relinquishes some of its market share to less efficient new entrants. ${ }^{97}$ Factors of production which are already underutilized in the market due to monopolistic output restriction are further misallocated to higher cost producers. ${ }^{98}$ Limit pricing in a monopoly market yields a lower price than um-

96.

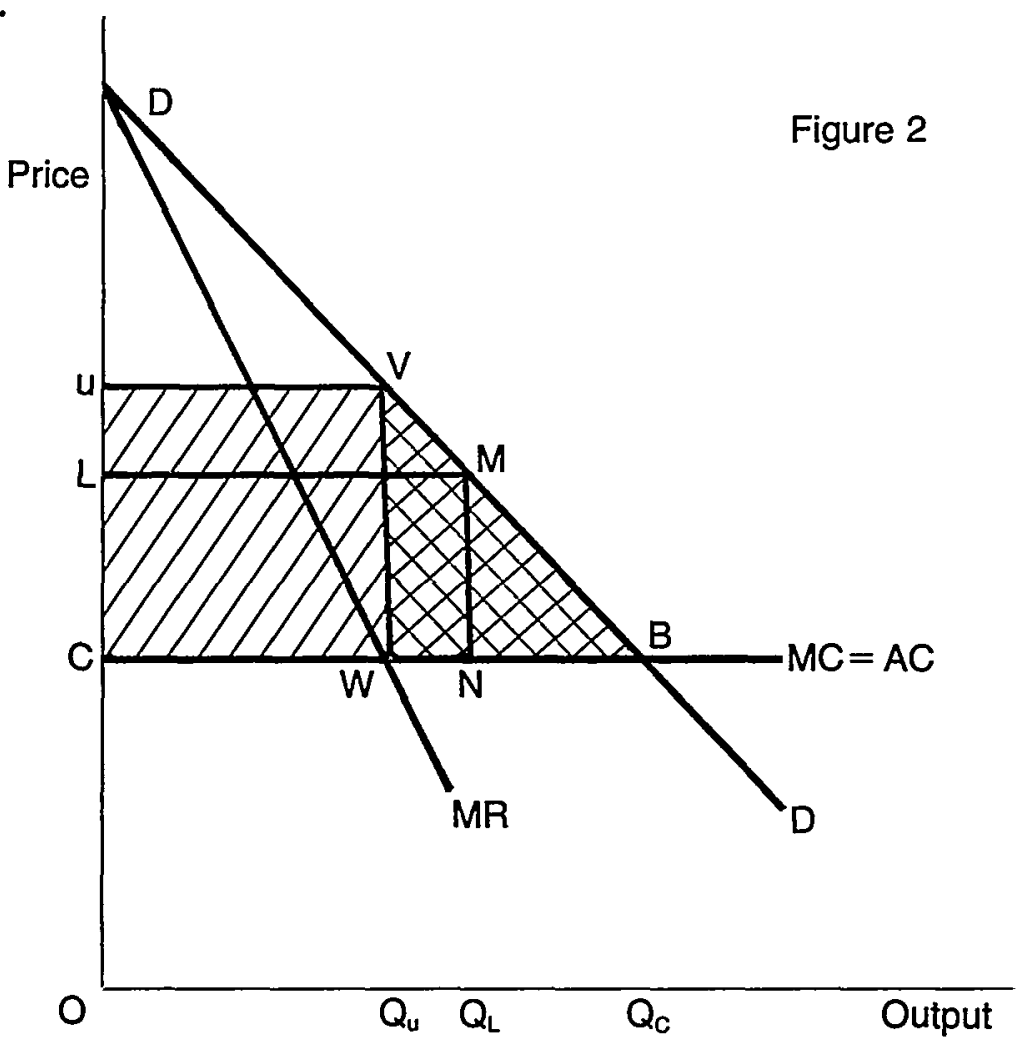

See note 16 supra for further explanations of Figure 2. At the competitive price $C$, output $Q_{c}$ is produced and resources are efficiently allocated. See ScHERER, supra note 4, at 18-19. Consumers receive a "surplus" of value $D C B$ above what they pay for output $Q_{c}$, and there are no excess profits (since cost includes a normal return to capital). At the short-run profit-maximizing price $U$, the monopoly earns excess profits $C U V W$. There is also a "deadweight" loss of $V W B$ due to misallocation of resources, which is lost by consumers but not gained by the monopoly. Id. at 13-19, 401 .

97. Because a monopoly may not lawfully erect artificial barriers to the entry of competitors, see p. 567 supra, the advantages a legitimate monopoly has over its competitors should be related to its efficiency. But see note 102 infra.

98. This explains why limit pricing increases both consumer welfare and long-run monopoly profits: An umbrella pricing monopoly must share its excess profits with less efficient producers, while a limit pricing monopoly will increase output and give the consumer a lower price, but keep all excess profits obtained at the limit price. 
brella pricing. Limit pricing will not occur unless the limit price is below the initial umbrella price. ${ }^{99}$ Even though the umbrella price declines as entry occurs, it can never fall below the limit price, since potential or actual competitors cannot enter or expand at any price below the limit price. ${ }^{100}$ The barriers which prevent the monopolist's competitors from entering or expanding below the limit price continue to operate if the competitors do enter or expand under a price umbrella. ${ }^{101}$ The only way to obtain a market price below the existing limit price is to reduce the barriers and thereby lower the limit price. ${ }^{102}$ Even the dynamic limit price, which is above the absolute entryforestalling limit price and permits some entry, is always below the umbrella price. ${ }^{103}$ Because of its lower price, the limit pricing firm

99. See pp. 562-63 supra.

100. See p. 562 supra.

101. It may be argued that competitors who gain a toehold under a price umbrella may be able to overcome the barriers and ultimately to produce at a lower price than the initial limit price. For example, the new entrant may grow to an efficient scale where it can compete with the monopoly; it may "learn by doing" and reduce the monopoly's cost advantage; or it may gain customer and investor confidence after prospering under a price umbrella and thereby lower its cost of capital and its selling costs. The answer to this argument is that disadvantages which the firm can overcome by toehold entry are really not barriers at all. A barrier permits the monopoly to raise its price persistently above the minimum average costs. See p. 560 supra. The term "persistently" is used to give a structural, long-run (i.e., five or ten years) aspect to the definition of entry barriers. J. BAIN, supra note 12 , at 7 .

Lack of production know-how and trained personnel constitute a temporary and nominal disadvantage to the new entrant, and such negligible barriers would never be reflected in the limit price. Id. at 148-49. Similarly, a new entrant will be able to grow to an efficient scale only if it faces an insignificant scale economy barrier. Scale economies impede entry or expansion not so much because of the "absolute capital requirement effect"-the need for large amounts of capital investment to achieve an efficient scalebut because of the "percentage effect"- where the efficient scale is a significant proportion of total industry capacity, entry at that scale can depress the market price below the entrant's costs. Id. at $53-56$. A firm which is able to grow to optimal size without depressing market price below its costs is facing at most an absolute capital requirements effect, not a percentage effect. The capital requirements effect depends on the existence of imperfections in the capital market and constitutes a barrier of questionable significance. Id. at 165 . Reducing capital costs by acquiring investor confidence also depends on capital market imperfections. If in fact those imperfections exist, there are better ways of correcting them (e.g., interest subsidies, accelerated depreciation, encouragement of large-firm diversification, id. at 215-16) than by inviting higher cost producers into the market.

It is of course true that the limit price may decline over time due to, e.g., technological diffusion, tariff repeal, or patent expiration. But such decline is not likely to result from the mere presence of competitors protected by a price umbrella. Any disadvantages overcome in this way should be ignored by potential entrants in estimating the limit price.

102. Williamson argues that market failure may permit the retention of a dominant position by a firm without efficiency-related advantages over its competitors. In this case, divestiture may be an appropriate remedy, although the threat of divestiture may encourage inefficient umbrella pricing to avoid attaining the threshold market share for a violation. Williamson, supra note 34 , at $1527 \&$ n.57; Turner, supra note 37 , at 1221 .

103. Gaskins, supra note 24 , at $310-11$, proves this result mathematically. Intuitively, since higher current prices imply lower future profits due to increased entry, the firm will price lower in the current period if it is balancing current against future profits (i.e., dynamic limit pricing) than it will if it is concerned only with current profits (i.e., umbrella pricing). 
allocates more resources to production in the monopoly market, and distributes some monopoly profits to the consumer. ${ }^{104}$ Given the initial monopoly position and existing entry barriers, limit pricing yields the best attainable economic results in the market.

Of the three economic models of monopoly pricing, only credible threat pricing should be illegal under the $\$ 2$ standard of "willful acquisition or maintenance" of monopoly power. Limit and umbrella pricing make use of existing market power; credible threat pricing adds to that power. Umbrella pricing exploits the short-run market power conferred by existing market share to maximize short-run profits. It ignores the constraint of potential competition and thereby results in an erosion of market share. Limit pricing exploits the long-run market power conferred by existing entry barriers to maximize longrun profits. It is a concession of the monopoly firm to the fact that the barriers are not high enough to allow it to price unconstrained by potential competitors. Credible threat pricing, on the other hand, creates an artificial barrier to competitors and allows the firm to umbrella price without losing its market share.

The Telex court made a fundamental economic error when it held that IBM's limit pricing was an attempt to create a barrier to entry. ${ }^{105}$ To require umbrella pricing by the monopoly firm deprives consumers of the lowest attainable market price. From an economic standpoint, limit pricing should be encouraged, not condemned, under $\S 2$ of the Sherman Act. ${ }^{106}$

\section{B. The Legal Rationale for Limit Pricing: The "Perceived Potential Entrant" Concept under $\S 7$ of the Clayton Act}

In its theory of potential competition developed in a line of merger cases under $\S 7$ of the Clayton Act, ${ }^{107}$ the Supreme Court has viewed

104. In Figure 2, supra note 96, output increases to $Q_{L}$ at the limit price $L$, monopoly profits decrease to $L M N C$, and the misallocation loss decreases to $M N B$. The result is a redistribution of income to consumers and an increase in allocative efficiency (assuming no second-best problems. SCHERER, supra note 4 , at 22-26).

105. 367 F. Supp. at 304 .

106. Limit pricing necessarily excludes less efficient potential competitors. It may therefore conflict with the noneconomic or social goal of antitrust policy-the protection of small business. United States v. Aluminum Co. of America, 148 F.2d 416, 427-29 (2d Cir. 1945); C. KAYSEN \& D. TURNer, supra note 13, at 17-18, 22. See M. AdelMan, supra note 80, at 418-25; Harlan \& Blake, In Defense of Antitrust, 65 Colum. L. Rev. 377, 382-84 (1965). Umbrella pricing protects competitors, but only by sacrificing the economic goals. The monopoly pricing issue forces the courts to choose between protecting competitors by requiring umbrella pricing or serving allocative efficiency and consumer welfare by encouraging limit pricing. A line of Supreme Court decisions under $\S 7$ of the Clayton Act provides strong legal authority for the limit pricing alternative.

107. United States v. Marine Bancorporation, Inc., 94 S. Ct. 2856 (1974); United States v. Connecticut Nat'l Bank, 94 S. Ct. 2788 (1974); United States v. Falstaff Brewing Corp., 410 U.S. 526 (1973); FTC v. Procter \& Gamble Co., 386 U.S. 568 (1967); United States v. 
limit pricing as the beneficial influence of potential entrants on a concentrated market, not as an exclusionary tactic which maintains monopoly or increases market power. This favorable view of limit pricing under the Clayton Act is inconsistent with judicial disapproval under $\S 2$ of the Sherman Act.

The Supreme Court has held that a merger between an established firm and a "perceived potential entrant" 108 may be illegal if it eliminates the restraining effect exerted on firms in the market by the potential competitor on the edge. ${ }^{109}$ The firms already in the market perceive the potential competitor as a likely entrant and reduce price to deter its entry; in other words, the presence of the perceived potential entrant forces the established firms to engage in limit pricing. ${ }^{110}$ The Court's reason for prohibiting the merger is to preserve the potential entrant as an impetus to limit pricing. ${ }^{111}$ There is no suggestion in

Penn-Olin Chem. Co., 378 U.S. 158 (1964); United States v. El Paso Natural Gas Co., 376 U.S. 651 (1964); United States v. Phillips Petroleum Co., 367 F. Supp. 1226 (C.D. Cal. 1973), aff'd mem., 94 S. Ct. 3199 (1974); United States v. Ford Motor Co., 286 F. Supp. 407 (E.D. Mich. 1968), aff'd, 405 U.S. 562 (1972). The Court's potential competition doctrine has generated a wealth of commentary. See, e.g., Berger \& Peterson, Conglomerate Mergers and Criteria for Defining Potential Entrants, 15 ANmrkusr Bull. 489 (1970); Handler, Twentieth Annual Antitrust Review-1967, 53 VA. L. REv. 1667, 1668-80 (1967); Robinson, Antitrust Developments: 1973, 74 Colum. L. Rev. 163, 180-90 (1974); Turner, Conglomerate Mergers and Section 7 of the Clayton Act, 78 HARv. L. REv. 1313, 1362-86 (1965); Note, United States v. Falstaff Brewing Corp.-Potential Competition under $\$ 7$ of the Clayton Act, 38 ALB. L. REv. 348 (1974); Note, United States v. Falstaff Brewing Corporation: Potential Competition Re-examined, 72 Mich. L. REv. 837 \& $n .2$ (1974) [hereinafter cited as Michigan Note]; Note, Toehold Acquisitions and the Potential Competition Doctrine, 40 U. Cri. L. Rev. 156 (1972); Note, United States v. Falstaff Brewing Corporation: $A n$ Examination of Potential Competition, 9 WAKE Forest L. REv. 545 (1973).

108. United States v. Marine Bancorporation, Inc., 94 S. Ct. 2856, 2878 (1974); United States v. Falstaff Brewing Corp., 410 U.S. 526 (1973) (Marshall, J., concurring). The Court has used a variety of other terms: $e . g$., "on-the-fringe potential competition" (id. at 534 n.13,537), "wings effect" (United States v. Marine Bancorporation, Inc., supra, at 2871). See also United States v. Phillips Petroleum Co., 367 F. Supp. 1226, 1232-34 (C.D. Cal. 1973) ("eđge effect"), aff'd mem., 94 S. Ct. 3199 (1974).

109. In addition to the "perceived potential entrant" effect, there is a second major branch of the potential competition doctrine: the likelihood that a potential competitor may actually enter the market on its own by establishing a new plant. The merger of an "actual potential entrant" with a firm already in the market eliminates the possibility of de novo entry (or toehold acquisition) by the potential competitor and the resulting stimulus to competition in the market. See United States v. Falstaff Brewing Corp., 410 U.S. 526, 560.62 (1973) (Marshall, J., concurring). For a case reaching this second branch, see United States v. Marine Bancorporation, Inc., 94 S. Ct. 2856, 2872 (1974).

110. The Court has referred in general terms to the perceived potential entrant's "beneficial influence on competitive conditions" without specifying the economic model underlying its analysis. United States v. Falstaff Brevving Corp., 410 U.S. 526, 532-33 (1974). But see FTC v. Procter \& Gamble Co., 386 U.S. 568, 593-94 (1966) (Harlan, J., concurring). However, commentators were quick to point out that the "perceived potential entrant" effect relied on the limit pricing model. See Berger \& Peterson, supra note 107, at 490-93; Handler, supra note 107, at 1671; Turner, supra note 107, at 1362-65; Michigan Note, supra note 107, at 841-53.

111. It may be argued that the Court is preserving potential entrants in order to require umbrella pricing which would invite them to enter. But the Court has said that its perceived potential entrant concept will apply even to a potential competitor unwilling or unable to enter on its own. See United States v. Falstaff Brewing Corp., 410 U.S. 526, 
the $\$ 7$ cases or commentary ${ }^{112}$ of the Telex view that limit pricing ought to be discouraged because it excludes potential competitors from the market. Rather, the Court has tried to insure that the lowest attainable price will prevail.

It may be argued that $\$ 7$ limit pricing cases are not relevant to suits arising under $\$ 2$. Section 7 cases have involved oligopoly markets with several sellers, ${ }^{113}$ rather than monopoly markets dominated by one firm. But oligopoly and monopoly limit pricing are the same economic phenomenon. Oligopolists will limit price only if they are acting like a joint monopoly. ${ }^{114}$ The Court's theory in attacking horizontal mergers under $\$ 7$ has been precisely that oligopoly closely approximates monopoly pricing behavior. ${ }^{115}$

Section 7 was amended to supplement the Sherman Act, which was thought not to reach certain mergers with anticompetitive effects. ${ }^{116}$ To violate $\$ 7$ a merger must result only in a probability of substantially lessening competition, ${ }^{117}$ not in a restraint of trade as required under $\$ 1$ of the Sherman Act or the power to control prices necessary under $\S 2 . .^{11 s}$ Even though the stringency of the test varies, however, a

532-33 (1973). See generally United States v. Phillips Petroleum Co., 367 F. Supp. 1226, 1234 (C.D. Cal. 1973), aff'd mem., 94 S. Ct. 3199 (1974). The Court's theory in these cases would seem to rest exclusively on encouraging the lowest possible price.

112. The desirability of limit pricing in a concentrated market, see pp. 576-79 supra, has generally been assumed in legal (and economic) analysis of limit pricing; the controversy has centered around whether limit pricing does in fact occur. Commentators have criticized the Court for neglecting the structural assumptions of the limit pricing model in its use of the "perceived potential entrant" concept. See, e.g., Handler, supra note 107, at 1672-75; Michigan Note, supra note 107, at 842-48. The Court's most recent decision on potential competition shows a closer attention to the assumptions necessary for a "perceived potential entrant" effect. United States v. Marine Bancorporation, Inc., 94 S. Ct. 2856, 2878-79 (1974) (acquiring bank not "perceived potential entrant" where regulatory barriers blockaded entry). Some commentators have suggested that these assumptions are so restrictive and unrealistic that limit pricing theory is of limited use in analyzing real world markets. See Berger \&. Peterson, supra note 107, at 490-93; Michigan Note, supra note 107 , at $848-49$. While these commentators are surely right in insisting that the assumptions be explicitly satisfied before the theory is applied to a particular market, their criticisms of the theory ignore the more sophisticated dynamic and probabilistic models which have replaced the simplistic early formulation. See p. 563 \& note 32 supra.

113. See cases cited in note 107 supra (least concentrated market to which "perceived potential entrant" concept applied is four firms with 61 percent of the New England beer market. United States v. Falstaff Brewing Corp., 410 U.S. 526 (1973)).

114. Oligopoly limit pricing assumes that firms tacitly or explicitly collude to maximize joint profits. See SCHERER, supra note 4, at 157, 218-19; notes 18, 19 supra.

115. United States v. Philadelphia Nat'l Bank, 374 U.S. 321, 363 (1963). See Brodley, Oligopoly Power under the Sherman and Clayton Acts-From Economic Theory to Legal Policy, 19 STAN. L. REv. 285 (1967).

116. Brown Shoe Co. v. United States, 370 U.S. 294, 317 \& n.33 (1962).

117. Id. at 323,325 .

118. For leading merger cases under $\$ 1$ of the Sherman Act, 15 U.S.C. $\$ 1$ (1970), see United States v. First Nat'l Bank \& Trust Co., 376 U.S. 665 (1964); United States v. Columbia Steel Co., 334 U.S. 495 (1948); International Shoe Co. v. FTC, 280 U.S. 291 (1930); United States v. Southern Pac. Co., 259 U.S. 214 (1922); United States v. Reading Co., 253 U.S. 26 (1920); United States v. Union Pac. R.R. Co., 226 U.S. 61 (1912). The latter three cases found a violation of $\$ 2$ of the Sherman Act as well. 
finding of a violation of any of these sections requires conclusions about the anticompetitive effects of market conduct. These conclusions should be measured by the same standard of market performance. The difference in the degree of market power required to trigger $\$ 2$ and $\S 7$ cannot justify a position that limit pricing is good under one statute but bad under the other.

Early cases under amended $\S 7$ took the view that the greater degree of market power required under $\S 2$ made its test for defining the relevant market inapplicable to $\S 7$ cases. $^{119}$ In its first decision ${ }^{120}$ under the new merger statute, however, the Supreme Court not only rejected this view but introduced a new "submarket" concept ${ }^{121}$ which it subsequently approved as a $\S 2$ standard as well. ${ }^{122}$ The courts have preserved consistency in their criteria for defining the relevant market under both sections; they should also do so in their criteria for evaluating conduct within that market. ${ }^{123}$

A $\S 2$ restriction on limit pricing would result in inconsistent treatment of the same economic phenomenon under two statutes with the

119. Crown Zellerbach Corp. v. FTC, 296 F.2d 800, 814 (9th Cir. 1961), cert. denied, 370 U.S. 937 (1962); United States v. Bethlehem Steel Corp., 168 F. Supp. 576, 588, 593 \& n.36 (S.D.N.Y. 1958).

120. Brown Shoe Co. v. United States, 370 U.S. 294 (1962).

121. Id. at 325 .

122. United States v. Grinnell Corp., 384 U.S. 563, 572-73 (1966). Lower courts have subsequently found submarkets under $\$ 2$. See, e.g., Case-Swayne Co. v. Sunkist Growers, Inc., 369 F.2d 449, 454 (9th Cir. 1966), rev'd on other grounds, 389 U.S. 384 (1967) (southern California orange submarket, relying on four $\$ 7$ cases); Credit Bureau Reports, Inc. v. Retail Credit Co., 358 F. Supp. 780 , 790 (S.D. Tex. 1971), aff'd on other grounds, 476 F.2d 989 (5th Cir. 1973) (credit reporting market divided into four submarkets).

123. Telex involves a particular misconstruction of $\$ 7$ precedent. The court relied on $\$ 7$ cases in limiting the market to IBM-compatible peripherals and in delineating separate submarkets for individual types of peripherals. $367 \mathrm{~F}$. Supp. at 336-37. Failing in its argument that the relevant market should include all computer systems because of substitution among components by users on the demand side, IBM argued that other systems should be included because of substitution on the supply side-the ability of other computer systems manufacturers to produce IBM-compatible peripherals interchangeably with peripherals for their own systems. Id. at $280,283-84,338$. In support of its "supply substitutability" theory, IBM cited the perceived potential entrant cases under $\$ 7$.

The court was correct in distinguishing these cases, but not because, as one commentator has suggested, Note, supra note 37 , at 889.90 , they are inapplicable under $\$ 2$. The Supreme Court first used the concept of supply substitutability to define the market in a Sherman Act vertical merger case, see United States v. Columbia Steel Co., 334 U.S. 495, $510-11$ (1948), and later approved it for use in vertical mergers under $\$ 7$, see Brown Shoe Co. v. United States, 370 U.S. 294, 325 n.42 (1962). Thus another Sherman Act market definition concept was transferred into $\$ 7$.

The perceived potential entrant cases do not involve supply substitutability at all. They are concerned with the influence of potential competitors on the conduct of firms inside an already defined market, not with the definition of the boundaries of that market. In fact, the theory behind these cases is that the potential competitors will not actually supply buyers in the market because existing firms will engage in limit pricing to prevent entry. After correctly distinguishing these cases on the market definition issue, however, the Telex court ignored them where they were relevant: the issue of IBM's conduct within the market. 
same economic purpose. Such inconsistency could lead to strange and unjustifiable consequences. For example, a potential competitor could sue a dominant firm under $\S 2$ for excluding it by limit pricing; ${ }^{124}$ but if it tried to buy the dominant it could be sued for eliminating the limit pricing.

To encourage limit pricing under one section of the antitrust laws but disallow it under another cannot be an effective antitrust policy. To achieve consistency, the $\S 7$ view of limit pricing should be adopted under $\S 2$. The $\$ 7$ view has the greater weight of legal as well as economic authority. The Supreme Court has repeatedly affirmed its "perceived potential entrant" concept in $\$ 7$ cases, while it has never dealt explicitly with limit pricing under $\S 2$. The restriction against limit pricing by a legal monopoly should be removed.

\section{Conclusion}

This Note has presented an economic and legal analysis of monopoly pricing under $\S 2$ of the Sherman Act. Under this analysis, IBM's pricing behavior in Telex $v . I B M$ is best interpreted as limit pricing. The Telex prohibition against limit pricing under $\$ 2$ conflicts with economic theory, which teaches that limit pricing yields the best attainable outcome in a monopoly market, and with the Supreme Court, which has sanctioned limit pricing in its potential competition decisions under $\$ 7$ of the Clayton Act. The Telex holding-that IBM's pricing actions violated $\S 2$ of the Sherman Act-should therefore be reversed.

124. See Credit Bureau Reports v. Retail Credit Co., 476 F.2d 989, 992-93 (5th Cir. 1973) (potential entrant entitled to injunction against exclusionary conduct by monopoly firm). 